\title{
Dynamic Simulations Supported Indoor Climate and Energy Building Modeling
}

\author{
István Kistelegdi and Bálint Baranyai
}

\begin{abstract}
The first energy-plus production facility in Hungary, which is developed with Energydesign ${ }^{\circledR}$ planning method and will be realized in 2012, reached its plus energy balance level with help of a special and holistic multidimensional design approach. The novelty of this method lies in dynamic building climate and energy simulations. With simulations supported building modeling complex, precise feedback is obtained already in the early stages of planning about the implications of various design ideas and conceptions in form of indoor climate and energy data. The difference of the performance and the consumption of alternating concepts or the different optimizing development steps of a building can be examined by way of detailed analysis. [1], [2] The optimized model and design plan of the south Hungarian energy-plus industrial and office project was validated with IDA ICE indoor climate and energy dynamic simulations. In this way the simulations ensure quantified effects of modifications due to the construction planning and to the realization of the construction.
\end{abstract}

Index Terms - Building climate, building energy, dynamic simulations, plus energy balance, geothermal power, solar energy, renewable energy, photovoltaics, solar thermal system, passive ventilation, passive cooling ventilation towers.

\section{INTRODUCTION}

Verification of the energy consumption of the simulated model in a project under implementation

The Energydesign ${ }^{\circledR}$ research group of the University of Pécs has developed a design method applicable for the building climate, energy and architectural technology modeling of plus energy buildings. The method of a multidimensional process arranges the systematic structured, carefully designed planning process, calculations, complex analysis and dynamic simulation control of buildings through a finite number of algorithmic steps. This problem-solving matrix creates sustainable solutions without common and widely used technical systems, whereby the positive energy balance of the building is a priori predefined. 3] The project is under construction and comprises a complex of a net floor area of approximately 2,500 $\mathrm{m}^{2}$, a storage facility a production hall, workshops, a central atrium, an innovation center, a restaurant-café, offices and sanitary rooms. One of the major features of the project is the dynamic building

Manuscript received June 18, 2012; revised January 7, 2013. This work was supported by the SROP-4.2.1.B-10/2/KONV-2010-0002, Developing the South-Transdanubian Regional University Competitiveness research and Development Program.

István Kistelegdi is with the University of Pécs, Pollack Mihály Faculty for Engineering and Information, Department for Energydesign, Boszorkány u. 2, 7624 Pécs, Hungary (e-mail: kistelegdis@gmail.com).

Bálint Baranyai is with the University of Pécs, Pollack Mihály Faculty for Engineering and Information, Department for Energydesign, Boszorkány u. 2, 7624 Pécs, Hungary (e-mail: baranyaibalint@gmail.com ). climate and energy simulation model of the planned structure, which verifies the design of the building.
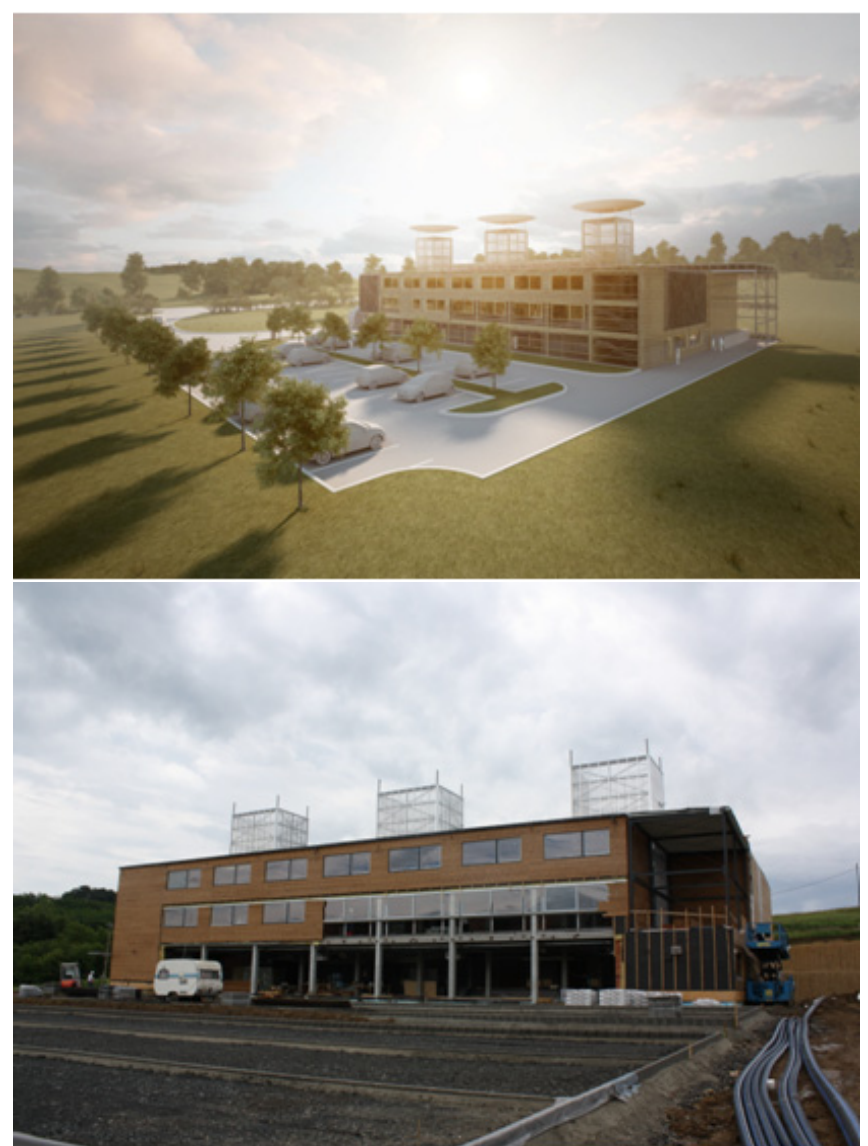

Fig. 1. Rendering form the northwest side of the plus-energy building mode (above), the real building - under construction, release in August 2012 (below).

Fig. 1 shows the complete building model with three passive cooling and ventilation towers and the north (main) façade. It is not only plan verification that can be performed with the help of simulation results however, but they can also be used for comparative analysis of the future values of the BMS building management system of a building. [4] The BMS measurements as simulations of a scale of $\mathrm{M}=1: 1$ thus verify the results provided by the software. The building will be fitted with a BMS system with integrated climate and energy monitoring, reference measurement spaces and control systems. [5]

\section{II. “ENERGYDESIGN” CONCEPT}

Low-temperature thermo-active heating-cooling surface system, embedded in reinforced concrete slabs (Fig. 2). The conditioning is based on a $32 \times 100$ meter ground probe 
system in transition seasons. In summer and winter the ground probes support three heat pumps.

Mechanical ventilation during the heating period and the hot summer period shows Fig. 2.

After being preheated by a $1060 \mathrm{~m}$ ground collector (air-ground heat exchanger), fresh air is directly sent to the production hall by way of induction.

Exhaust air departs through the atrium roof and ventilation towers on the roof due to thermal buoyancy and special developed "Venturi" aerodynamic boundary layer accelerator disc constructions. [6]

Preheated air by ground collector is further heated by the heat recovery systems in winter; afterwards the functional spaces are supplied with fresh air in a mixed way.

A special feature of the mechanical ventilation system is that the trash air collected from the upper floor offices is thermally used twice. This exhaust air is aspirated into ventilation channels, which are integrated in the passive cooling ventilation towers and supply the used air into the factory hall. The production zone, flushed through by the air thus heated, gains an extra heating effect; then the entire volume of used air releases heat for a third time in the plate type heat recovery system (with an efficiency of $60 \%$ ) and finally, as a fourth step, the exhaust air is discharged into the storage facility, which is tempered by the air warmth of approx. $11^{\circ} \mathrm{C}$ temperature.

Natural ventilation during the transitional seasons is ensured through the facade openings and the towers in the production hall, as well as through the ventilation system of the skylights and the doors of the atrium. [7]

A solar thermal collector and buffer storage system provide $100 \%$ of hot water.

The remaining part of the total final energy demand can be powered in a second stage of development through the overproduction of the photovoltaic cell modules in the building envelope (plus energy balance).

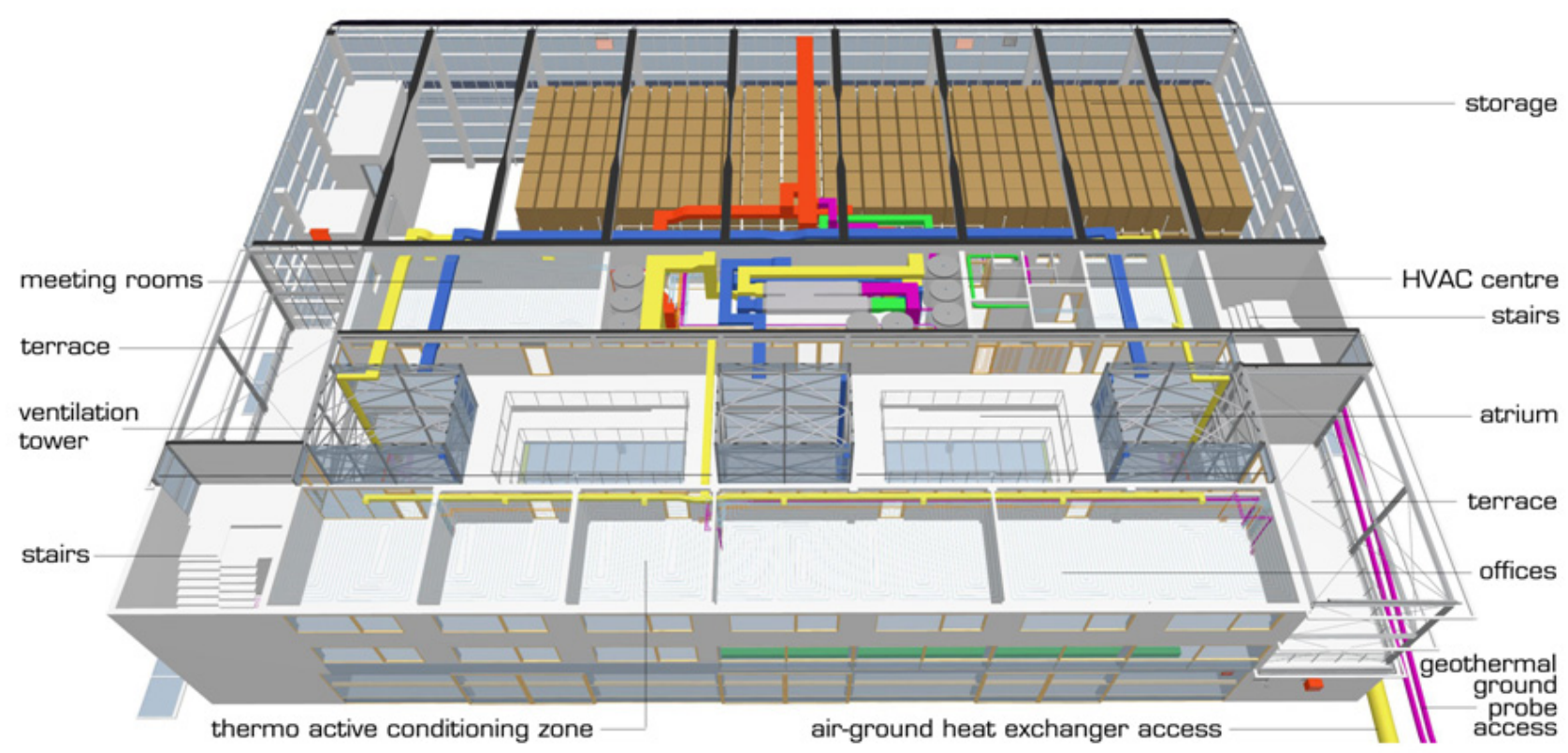

Fig. 2. Floor of the building with the HVAC center, ventilation ducts and thermo-active conditioning system.

\section{SimUlATION CONCEPTS}

With the use of the IDA ICE 4.0 Indoor Climate and Energy software, a complex model comprising eight building bodies and 53 climatic zones was set up based on detailed construction data and the specification of layers (Fig. 3). To be able to simulate the relation of the heating, cooling and transitional periods, three models had to be set up with different settings as a function of the possible building structure and building services adjustment options (Concept 1). Due to the partly useless, unrealistic results of the short pre-simulation (start up) and simulation periods, Concept 1 had to be replaced by Concept 2 featuring two models (a heating and a cooling model), in which the hypothetic presumed time intervals of the heating and cooling periods could be properly specified. Simulation results of Concept 3 featuring precise time settings indicated overheating in the atrium as a buffering zone when examined for building climate and sense of comfort and well-being. With the help of test simulations in Concept 4 the climatic performance properties of the major areas in the building were optimized [8], [9] - after multiple fine tuning of the mechanical ventilation, window and facade natural ventilation, the openings of the passive ventilation tower and the skylights of the atrium, the passive cooling in the night and the shading schedule plans. Fig. 4 displays the operative temperature in an average summer day. 


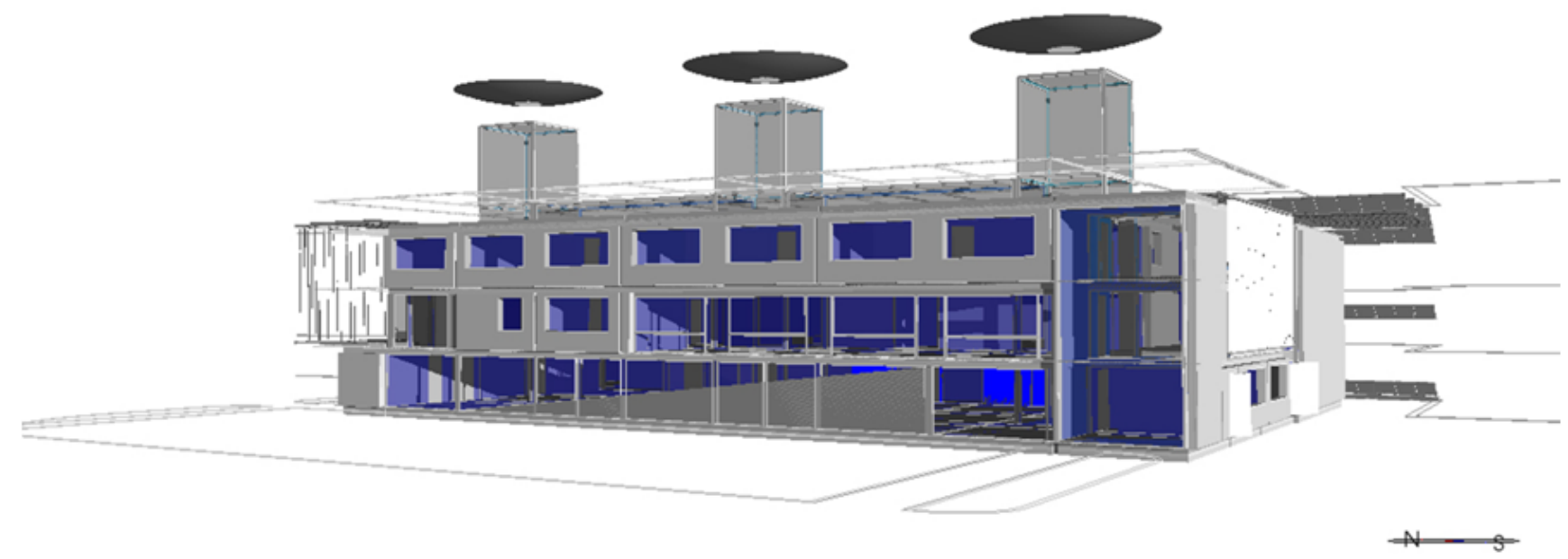

Fig. 3. Multi-climate zone model in the IDA ICE simulation application.

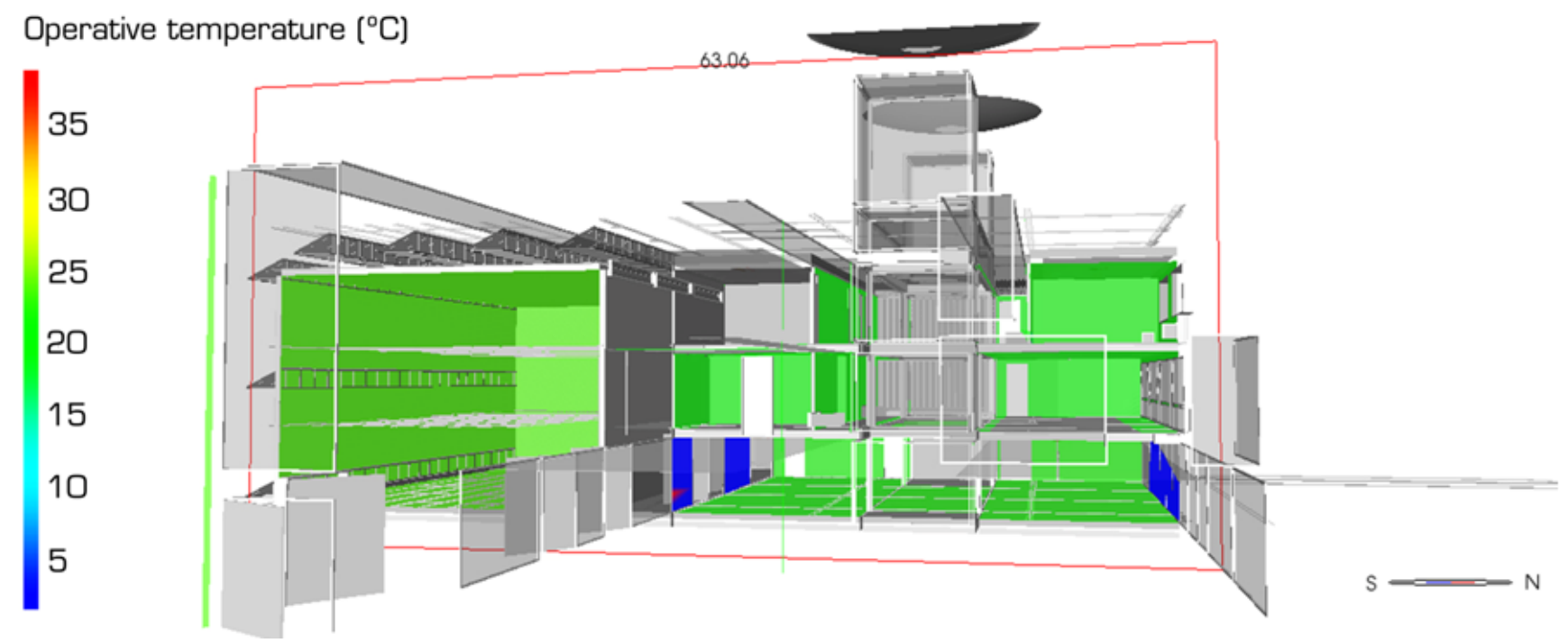

Fig. 4. Operative temperatures in 2010-07-12, time: 16:10 (approval plan model).

\section{ENERGY BALANCE}

After the appropriate adjustment and the dynamic simulations of the building climate, the next step was to examine building energy quality and to set up an energy balance. The dynamic calculation process of the building climate and the final electricity consumption generates its results by using ASHRAE IWEC 1.1 meteorological weather files as input data. [10] A $1060 \mathrm{~m}$ long ground-air collector and 32 pieces of $100 \mathrm{~m}$ deep ground probes were integrated in the simulation. In compensation for the lack of a ground probe option in the simulation program, the efficiency of the heat pump was increased (COP Coefficient of Performance value of 12 applied instead of 5) to simulate the geothermal power. The electricity consumption of the production hall and the office building is the total sum of the energy demand of the thermo-active surface heating-cooling system, mechanical ventilation, artificial lighting, office equipment and production equipment: summa $82,364 \mathrm{kWh} / \mathrm{a}$, that is 36
kWh $/ \mathrm{m}^{2} \mathrm{a}$ (Fig. 5 - 8). April and October were calculated from the heating model (higher consumption - evaluation security). This means that the building achieves values better than those of the German building energy standard of KfW 40. $\mathrm{Kfw}=$ Kreditanstalt für Wiederaufbau, KfW $40=$ primary energy demand $40 \mathrm{kWh} / \mathrm{m}^{2} \mathrm{a}$. Due to the fact that the photovoltaic electricity can be calculated with a primary energy factor 1 , the $36 \mathrm{kWh} / \mathrm{m}^{2}$ a electric energy consumption can be covered through solar primary energy gains.

On the other side of the energy balance is the electricity produced by the photovoltaic power generating building envelope.

An advanced calculation, based on a DIALUX natural lighting simulation [11] and the METEONORM climate database values of average global radiation and sunshine duration, gives a result of $88,160.55 \mathrm{kWh} / \mathrm{a}$ solar electricity production. Therefore, the energy balance of the building indicates a plus energy production of $5,796.55 \mathrm{kWh} / \mathrm{a}$. 


\begin{tabular}{|c|c|c|c|}
\hline & & \multicolumn{2}{|c|}{ Delivered energy } \\
\hline & & kWh & $k W h / m^{2}$ \\
\hline Г & Lighting, facility & 8175 & 3.0 \\
\hline [ & Cooling & 1105 & 0.4 \\
\hline ए & HVAC aux & 785 & 0.3 \\
\hline & Total, Facility electric & 10065 & 3.7 \\
\hline & Heating & 0 & 0.0 \\
\hline & Domestic hot water & 6896 & 2.6 \\
\hline & Total, Facility fuel* & 6896 & 2.6 \\
\hline & Total & 16961 & 6.3 \\
\hline$\square$ & Equipment, tenant & 26643 & 9.9 \\
\hline & Total, Tenant electric & 26643 & 9.9 \\
\hline & Grand total & 43604 & 16.2 \\
\hline
\end{tabular}

Fig. 5. Delivered final energy report of the cooling model (overview) - approval plan phase.

\begin{tabular}{|c|l|c|c|}
\hline \multicolumn{2}{|c|}{} & \multicolumn{2}{l|}{ Delivered energy } \\
\cline { 3 - 4 } & kWh & $\mathbf{k W h} / \mathbf{m}^{\mathbf{2}}$ \\
\hline$\square$ & Lighting, facility & 10806 & 4.0 \\
\hline$\square$ & Cooling & 0 & 0.0 \\
\hline$\square$ & HVAC aux & 3082 & 1.1 \\
\hline & Total, Facility electric & 13888 & 5.1 \\
\hline & & & \\
\hline$\square$ & Heating & 15263 & 5.7 \\
\hline$\square$ & Domestic hot water & 6864 & 2.5 \\
\hline & Total, Facility fuel* & 22127 & 8.2 \\
\hline & Total & 36015 & 13.4 \\
\hline$\square$ & Equipment, tenant & 26843 & 9.9 \\
\hline & Total, Tenant electric & 26843 & 9.9 \\
\hline & Grand total & 62858 & 23.3 \\
\hline
\end{tabular}

Fig. 6. Delivered final energy report of the heating model (overview) - construction plan phase.

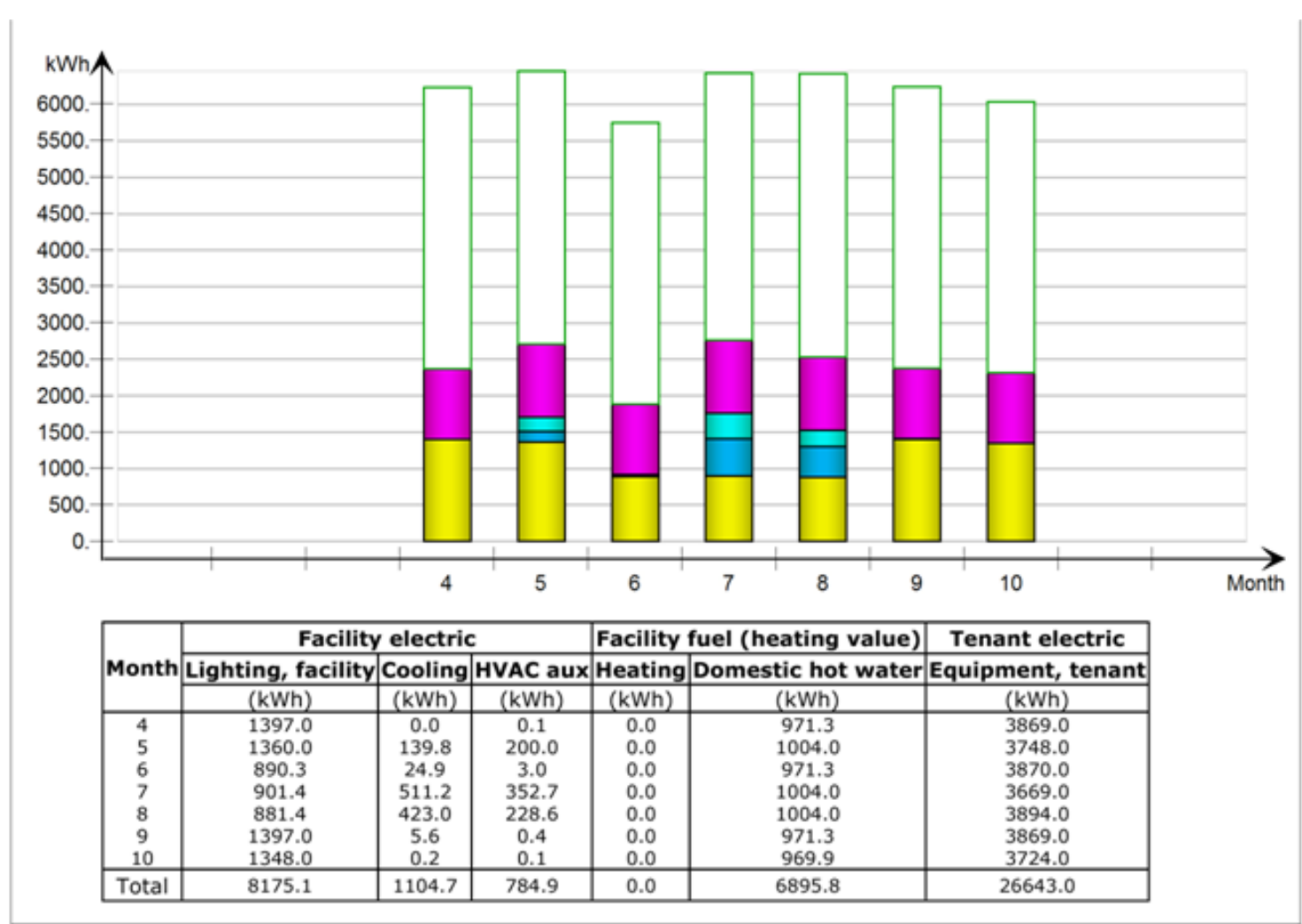

Fig. 7. Monthly delivered final energy report of the cooling model - approval plan phase. 


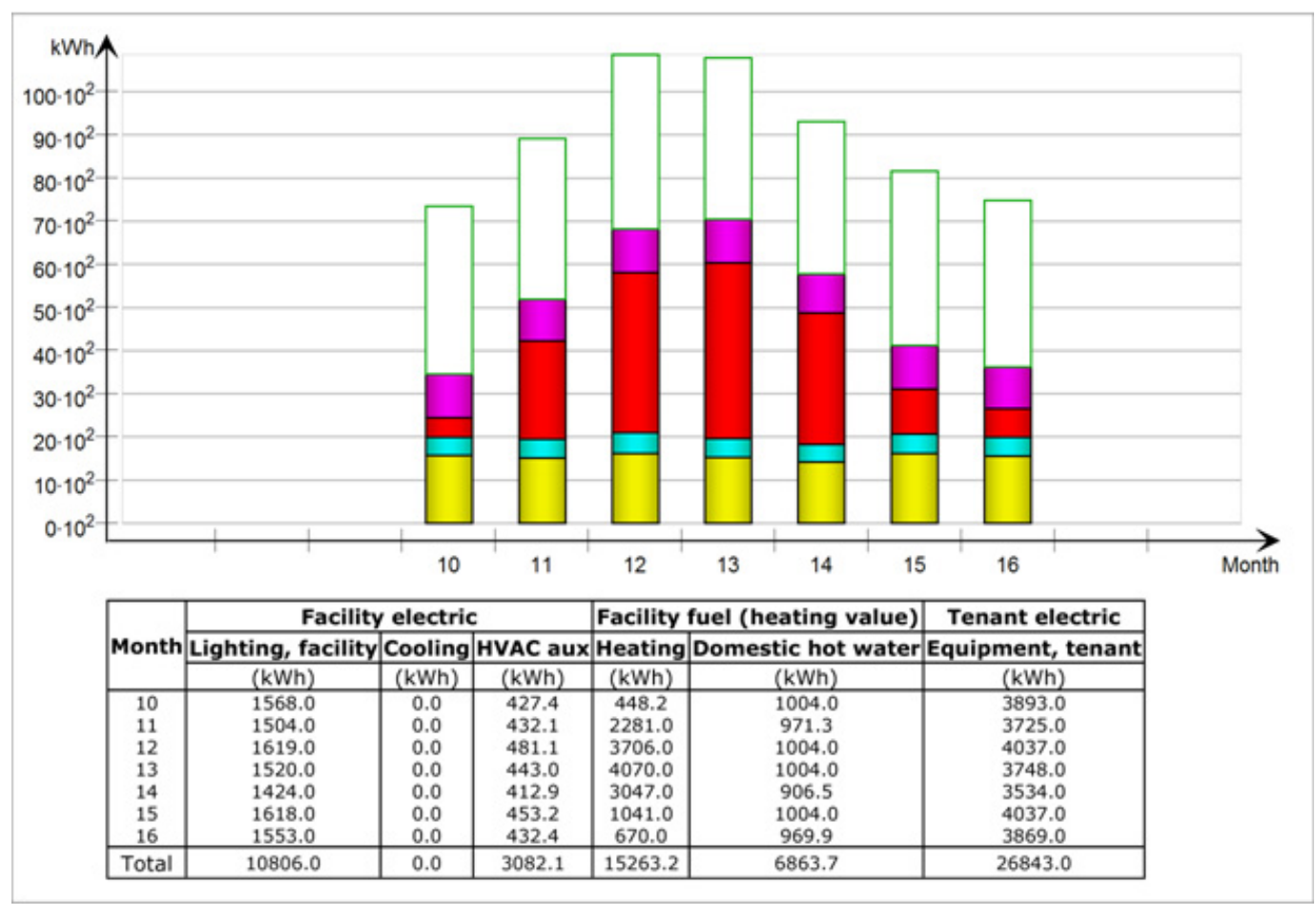

Fig. 8. Monthly delivered final energy report of the heating model - construction plan phase.

The Energydesign concept was tested in a series of simulations with positive result. The effectiveness of the mechanical ventilation system, the surface heating-cooling system, the heat pumps and the near-surface geothermal energy system, and at the same time the climate performance of the building were verified for both winter and summer periods, with the exception of two or three transitional months when the slow heat transfer of the thermal mass and storage system was unable to dim the amplitude of external temperature fluctuation inside the building. In these periods the temperature of the atrium followed the external temperature alterations, while the functional areas were either overheated or undercooled with mechanical or natural ventilation. It can be concluded from the analysis that in certain zones heating is still required, while in other zones it is advisable to switch to cooling mode.

\section{SimULATION OF THE CONSTRUCTION PLAN}

After the completion of the construction planning thermal masses were increased, due to the fact that a reinforced concrete frame structure was designed (reducing costs) and it was possible to use wooden lightweight concrete thermo-active conditioning systems [12]. The inductive research will be continued with new simulations with the fine-tuning data of the construction-plan-level building services and building structure. These calculations confirm the climate and energy quality of the updated construction project, which can be further optimized if necessary. The new simulation of the cooling model verifies that the 18,028 $\mathrm{kWh} / \mathrm{a}$ final energy demand of the construction plan (excluded production technology consumption) - as compared to the $16,961 \mathrm{kWh} / \mathrm{a}$ demand of the approval planning - delivers only minimal extra need for artificial lighting, active cooling and ventilation and 4,729.55 kWh/a extra plus energy production.

\section{CONCLUSION}

The best possible building climate conditions can be developed in the construction plan simulations. These calculations prepare the BMS and MMS (Mobile Management System) building monitoring and control measurement research. The results will be compared with the measured building climate and energy values in order to verify the design concept and the simulation data.

\section{REFERENCES}

[1] Mengedoht and Hausladen G., Dynamische Gebäudesimulationen (Dynamic Building Simulations), Technik am Bau 03/2002, pp. 97-102, 2002.

[2] L. M. Hensen J. and R. Lamberts, Building Performance Simulation for Design and Operation, Spon Press, Abingdon, Oxon, pp. 505, 2011.

[3] I. Kistelegdi, ROADMAP für den Energiedesign polydimensionalen Entwurfsprozess, Exemplarische gebäudeenergetische, -klimatische und -technologische Modellierung von Plusenergiegebäuden - am Fallbeispiel eines Realisierungsbauvorhabens für ein Industrie und Bürogebäude, (ROADMAP for the polydimensional Design Process, Exemplary Climate, Energy and Technology Modelling of Energy-Plus Buildings - Case Study of an implemented Industry- and Office Building, Publication in progress 2013.

[4] B. Póth and I. Kistelegdi, Energy and climate simulations and management system in the Szentágothai Research Centre, POLLACK PERIODICA Publication in progress 2013.

[5] Welltech Zrt, P\&I Plan and Operation Manual Description of the RATI BMS System.

[6] I. Kistelegdi and I. Háber, Building aerodynamic investigations for an energy-plus production facility in Sikonda (Hungary), Bauphysik 34 (2012), Heft 3, pp. 107-120, Ernst und Sohn, Wiley.

[7] B. Bauhofer, Rati Windkanalstudie, Natürliche Lüftung, Produktionshalle, Atrium und Lager, (Wind Tunnel Study, Natural Ventilaton Production Hall, Atrium, Storage), GfA Gesellschaft für Aerophysik mbH, 2011, Munich.

[8] MSZ EN 15251: 2007 (CEN, 2007), Indoor environmental input parameters fort he design and assessment of energy performance of buildings-addressing indoor air quality, thermal environment, lighting and acoustics.

[9] MSZ CR 1752:2000 Ventilation for buildings - Design Criteria for the Indoor Environment 
[10] American Society of Heating. Refrigerating and Air-Conditioning Engineers. [Online]. Available: www.ashrae.org

[11] R. Jóni, Simulation and calculation of the monthly reference solar global radiation and illuminance values in Komló (Hungary) for the purpose of photovoltaic enegy gain calculations, 2010.

[12] I. Kistelegdi, M. Baumann, L. Lenkovics, and L. Budulski, Ökobeton fütú-hủtő panel fütési-hütési teljesítmény mérése (Measurements of the Heating-Cooling Power Performance of Eco-Concrete Heating-Cooling Panel), University of Pécs, Mihály Pollack Faculty of Engineering and Information Technology, Department for Buidling Services, 2012.

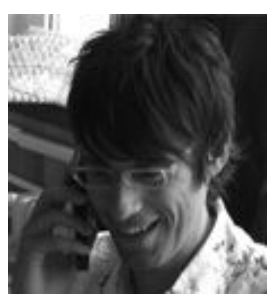

István Kistelegdi was born in Pécs, Hungary 1972. He received his B.S. degree as Architect from Fachhochschule Würzburg, and his M.S. degree from University of Kassel, M.S. degree as Climate Designer from TU-München, DLA from University of Pécs. During and after his study he did 10 years work experience in Germany as an architect. He has been teaching since 2006 at the University of Pécs. Dr. Kistelegdi currently is an assistant professor and since 2010 Head of Department for Energy Design. His research interests include: Design and simulation modeling of energy efficient residential buildings, energy management monitoring of public buildings, multifunctional adaptive climate systems in the building envelope, building aerodynamics modeling, energy optimized built heritage protection and reconstruction.

Bálint Baranyai was Born in Pécs 1968. He received his M.S. degree from Technical University of Budapest. He has been working for 20 years as architect in Hungary. Mr. Baranyai currently is research assistant in the energy design research team at the University of Pécs. 